PLANTS PEOPLE

POSSIBILITIES

\title{
Dipentodon. A New Genus of Uncertain Systematic Position
}

Author(s): S. T. Dunn

Source: Bulletin of Miscellaneous Information (Royal Botanic Gardens, Kew), Vol. 1911, No. 7 (1911), pp. 310-313

Published by: Springer on behalf of Royal Botanic Gardens, Kew

Stable URL: http://www.jstor.org/stable/4119481

Accessed: 27-06-2016 03:29 UTC

Your use of the JSTOR archive indicates your acceptance of the Terms \& Conditions of Use, available at

http://about.jstor.org/terms

JSTOR is a not-for-profit service that helps scholars, researchers, and students discover, use, and build upon a wide range of content in a trusted digital archive. We use information technology and tools to increase productivity and facilitate new forms of scholarship. For more information about JSTOR, please contact support@jstor.org.

Royal Botanic Gardens, Kew, Springer are collaborating with JSTOR to digitize, preserve and extend access to Bulletin of Miscellaneous Information (Royal Botanic Gardens, Kew) 
in a nursery. Male flowering trees are preferable to female, for when the latter are fruiting, the cottony fibre which surrounds the seeds is apt to become objectionable.

Populus Eugenei, Simon-Louis.-Although there are several species of poplar which are, or may be, grown successfully in this country, experiments might well be directed towards ascertaining whether some of the hybrids, on account of more robust growth, would not be more profitable. Cultivated as ornamental trees they are certainly more vigorous than their parents and it is quite possible that they would produce a given amount of timber of equal or better quality in a shorter space of time. The hybrids are probably of natural origin, but, until recently, they have been considered to be varieties of certain species, or have been distributed as good species. Their identity has, however, been worked out by Henry and others, and they have been proved pretty conclusively to be hybrids between the European $P$. nigra, L. and one of the American species, $P$. monilifera, Ait., or $P$. angulata, Ait.

$P$. Eugenei is likely to prove one of the best of these hybrids for forest planting, for it is of sturdy, pyramidal habit, with a narrow head of small branches. It grows rapidly and will apparently arrive at a marketable age in 30 or 40 years from the time of planting. Growing in poor sandy soil at Kew, which often becomes very dry-by no means ideal conditions for poplars-a tree planted in 1888 is now 95 feet high, 7 feet in girth near the ground, and 4 feet $10 \frac{1}{2}$ inches at 5 feet high. It is a male plant and would of course have to be increased by means of cuttings. Pure stands on moist ground would doubtless be more economical than mixed woods and the trees might be planted from 3 to 4 feet apart each way. Like other poplars it is well adapted for the banks of lakes and streams, hence its suitability for plantations on marshy ground.

$P$. serotina, Hartig, $P$. regenerata, Hort., $P$. marilandica, Bosc. and $P$. robusta, Schneider, are other vigorous-growing hybrids, which, when grown in the open, develop wide-spreading heads of branches. Some of them are already in cultivation included under the general term of black Italian Poplar. All are worth trying in experimental blocks.

\section{XL.-DIPENTODON.}

\section{A New Genus of Uncertain Systematic Position.}

\section{S. T. Dunn.}

In $1898 \mathrm{Mr}$. Augustine Henry sent to Kew from Mengtze in Yunnan, where he was then stationed as Commissioner of Customs, specimens of the foliage and young fruits of a small tree growing in the forests which covered the mountains to the south of that town. The specimens exhibited such unusual floral characters that there arose some doubt, which further study failed to remove, as to what Natural Order or even as to what Series of the Dicotyledons could be expected to contain its allies. The material was, in fact, not sufficiently complete to enable the question to be decided until, among some specimens from the Province of 
Kweichau communicated to Kew by Mgr. Léveillé, Perpetual Secretary of the Academie Internationale de Géographie Botanique, was found excellent and abundant material of the same species in flower and fruit.

Even with the complete series of specimens now available, approximately close allies have not been found, but it has been placed provisionally, as a new genus, among some anomalous monotypic genera in Celastraceae. The name Dipentodon, proposed for it, refers to the most remarkable character possessed by the flowers in the exact similarity of the calyx teeth and petals (if I rightly call them so) and their insertion so nearly in one whorl that the appearance is given of a ten-toothed perianth.

Dipentodon, Dunn, gen. nov. [Celastraceae-Elaeodendreae ?] ; ob ovarii indolem Tripterygio, Hook. f., comparabile.

Calyx 5-fidus ; tubus urceolatus, disco adhaerens ; lobi erecti, ligulati, aestivatione aperti. Petala 5, calycis lobis omnino similia. Stamina 5, disco inserta, calycis lobis opposita, glandulis alternantia, filamentis filiformibus, antheris didymis. Ovarium liberum, basi 3-loculare, apice 1-loculare, in stylum integrum attenuatum; ovula in loculis imperfectis 2, erecta. Capsula septicide dehiscens, obtuse 3-gona, stylo terminata, coriacea, septis evanidis 1-locularis. Semen erectum, testa carnosa. Embryo minutus, intra basin albuminis situs, rectus, cylindricus, axilis.-Arbores parvi. Folia alterna, petiolata, serrulata, stipulata. Umbellae parvae, pedunculatae, axillares.

D. sinicus, Dunn (species unica).

Arbor parva, ramulorum cortice siccitate nigra. Folia alterna, lanceolata, in acumen longum gradatim angustata, basi breviter acuminata, ad $14 \mathrm{~cm}$. longa, per totam marginem regulariter calloso-serrulata, papyracea, primum in costa subtus pubescentia, mox praeter basin glabra, tandem omnino calva, nervis utrinque 7-9; petioli 3-6 $\mathrm{mm}$. longi ; stipulae membranaceae, lanceolatae, 5-7 mm. longae, caducissimae. Umbella longipedunculata, globosa, 25-30-flora, 1-1.5 $\mathrm{cm}$. diametro, 4-5 bracteis ovatis caducis involucrata ; pedunculus axillaris, $2 \cdot 5-3.5 \mathrm{~cm}$. longus, pubescens. Flores luteoli, parvi, $2 \mathrm{~mm}$. longi, primum dense pubescentes, diu fere glabri; pedicelli puberuli, $3 \mathrm{~mm}$. longi, post anthesin elongati, medio articulati. Calycis campanulati laciniae 5, aestivatione apertae, primum irregulariter inflexae, tandem erectae, ligulatae, apice rotundatae, tubum bis excedentes. Petala 5, cum calycis laciniis simillimis alternantibus specie in serie una inserta. Stamina 5 erecta, sub anthesi calyce paullo longiora. Disci glandulae quartam partem calycis laciniarum aequantes, apiculatae. Ovarium ellipticum, ad basin apicemque angustatum, superne in stylum integrum ovario paullo breviorem angustatum, pilis longis lanosis vestitum, imperfecte 3-loculare, stylo glabro apice rotundato; ovula in loculorum basibus per paria erecta. Capsula e calyce longe exserta, elliptica, in stylum abrupte angustata, praeter stylum 6-9 mm. longa, breviter velutina, unilocularis; valvae 3 , coriaceae. Semen unicum, anguste ellipticum, 4-5 mm. longum, brunneum, in placenta centrali post anthesin elongata $2 \mathrm{~mm}$. longa ovulis abortivis et septorum vestigiis coronata sedens. 
Crina. Yunnan : Mengtze, S. Mountain Forests, 1800 m., Henry, 10,741 ; Kweichau : Long-Ly, Cavalerie, 2995 ; Kiangouang: Pin-fa, Cavalerie, 2353 ; Majo, Cavalerie, 3313.

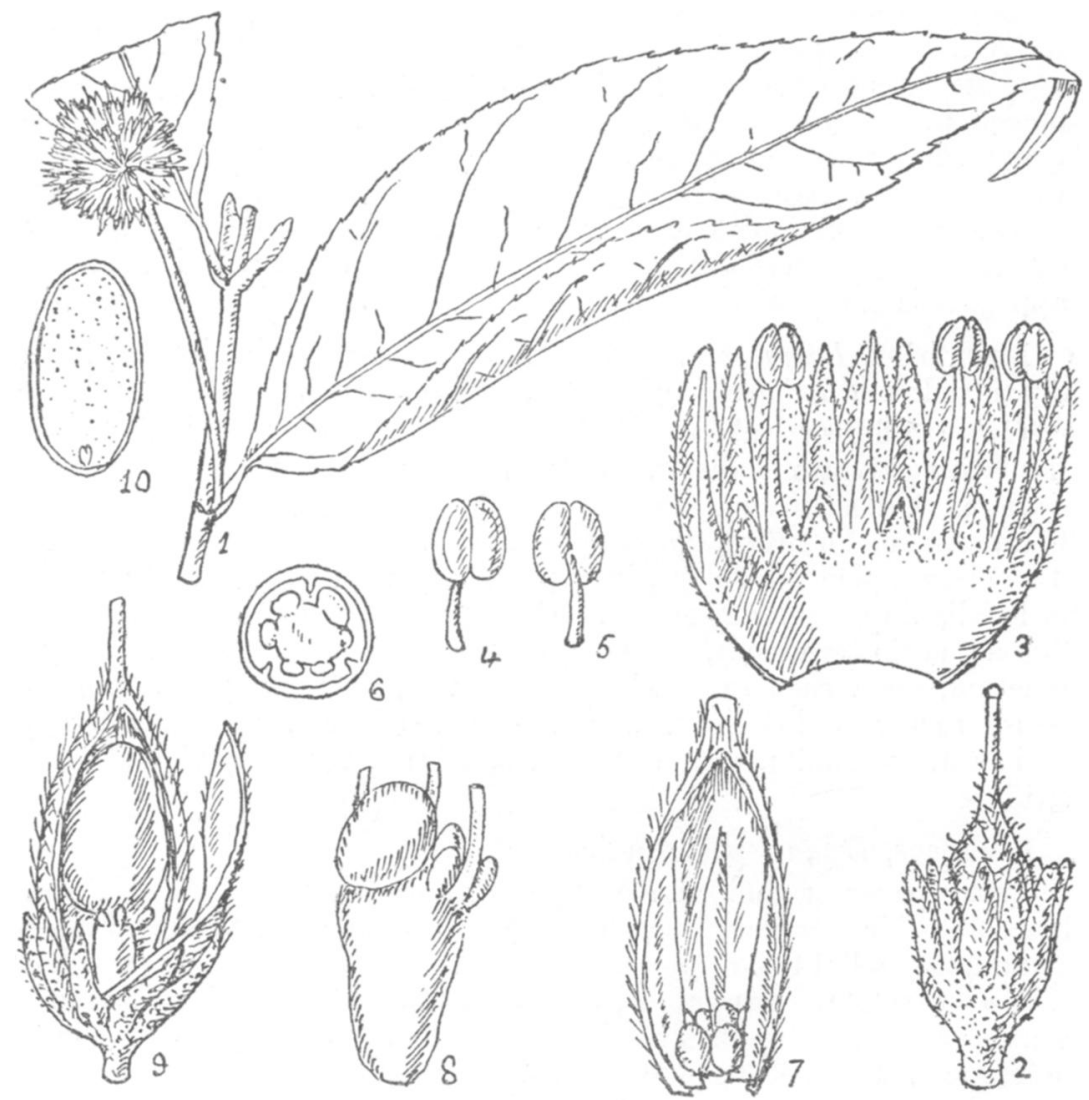

1. Portion of twig with inflorescence (nat. size).

2. Late stage of flower $(\times 5)$.

3. Ditto $(x 8)$ laid open after removal of gynoecium.

4,5 . Front and back of upper part of stamen $(\times 12)$.

6 . Cross-section of upper portion of ovary $(\times 7)$, some time after fertilisation, showing six ovules surrounding the top of the placenta (compare n. 8), one of them already predominating, and the three partial dissepiments.

7. Young ovary $(\times 40)$ laid open showing the six ovules about the time of fertilisation before the upward growth of the placenta and separated into pairs by the partial dissepiments.

8. Advanced placenta $(\times 10)$ removed from the ovary, bearing fragments of the bases of the partial dissepiments torn off in its upward growth and the ovules at the same stage as in n. 6 .

9. Capsule $(\times 4)$ dehiscing and showing the single seed and some undeveloped ovules borne on the columnar development of the basal placenta.

10. Longitudinal section of a seed $(\times 6)$ showing the minute basal embryo.

Dipentodon, as has been mentioned, is characterised by a combination of structural peculiarities that does not find an even approximate counterpart in any other genus known to me, and the discovery of the Natural Order to which it is most nearly allied has therefore presented considerable difficulties. The situation has, moreover, been complicated by the ambiguous character of 
the outer floral whorl and of the androecium. The outer covering of the flower appears at first sight to have 10 similar ligulate teeth, and these may be regarded as 5 sepals and 5 petals or as 10 sepals, the petals being absent. The staminal whorl is also capable of two explanations, according as the 5 glands alternating' with the stamens are considered to be reduced members of a decamerous androecium or merely as projections of the disc.

The ten teeth of the perianth though quite similar and apparently in one row can, in the young bud, be distinctly seen to form an inner and outer whorl and even up to maturity the edges of five of the teeth are slightly within those of the alternate ones. It may be said therefore that these two whorls represent a calyx and a perigynous corolla. The position of the stamens opposite to the outer members or calyx segments is in accordance with that view.

The diagnosis of the genus has been drawn up upon the above interpretation of these whorls and will allow of its being placed provisionally in Celastraceae near Tripterygium with which it is in close agreement regarding ovary characters.

It is true that Dipentodon differs in several structural points from the greater part of the Celastraceae but each peculiarity is shared by one at least of the genera comprised by Bentham and Hooker in that Natural Order. The similarity of the calycine whorl to the corolla and their open aestivation is paralleled by some species of Perrottetia ; the five glands of the disc, if taken to represent a step towards a decamerous androecium throw light upon the position of Glossopetalum, which, with its ten stamens, has hitherto held an unique position in the Natural Order ; the septicidal dehiscence of the capsule is unusual but closely resembles that of Microtropis and perhaps of other allied genera in which a single seed results from a plurilocular ovary ; the curious growth of the placenta beneath the six basal ovules, in consequence of which the seed is at length borne on a short stalk within the capsule is similar to that which occurs in Kurrimia; the stipules and the umbellate inflorescence agree with the monotypic S. American genus Goupia.

If Dipentodon is rightly placed in Celastraceae at all, it is only in consequence of its connection with the main body of that Natural Order through the genera Tripterygium, Perrottetia, Kurrimia and Goupia. These differ among themselves as much as they do from the greater part of the rest of Celastraceae, and it is among the isolated groups which they form on the fringe of the Order that Dipentodon may be provisionally left.

The anatomical characters have been examined by $\mathrm{Mr}$. Boodle but do not appear to give any clear indication of the affinities of the genus.

\section{XLI.-DIAGNOSES AFRICANAE: XLIV.}

1281. Mesembryanthemum oculatum, N. E. Brown [FicoideaeMesembryeae]; affine $M$. viridifloro, Ait., sed ramis multo brevioribus, foliis confertioribus, floribus albis rubro-orulatis differt.

Herba perennis, subcaespitoso-ramosa, papulata, ramis $2-6 \mathrm{~cm}$. longis procumbentibus. Folia $0 \cdot 7-3 \mathrm{~cm}$. longa, basi 4-6 mm. lata, deinde ad apicem obtusum angustata, supra leviter concavo- 